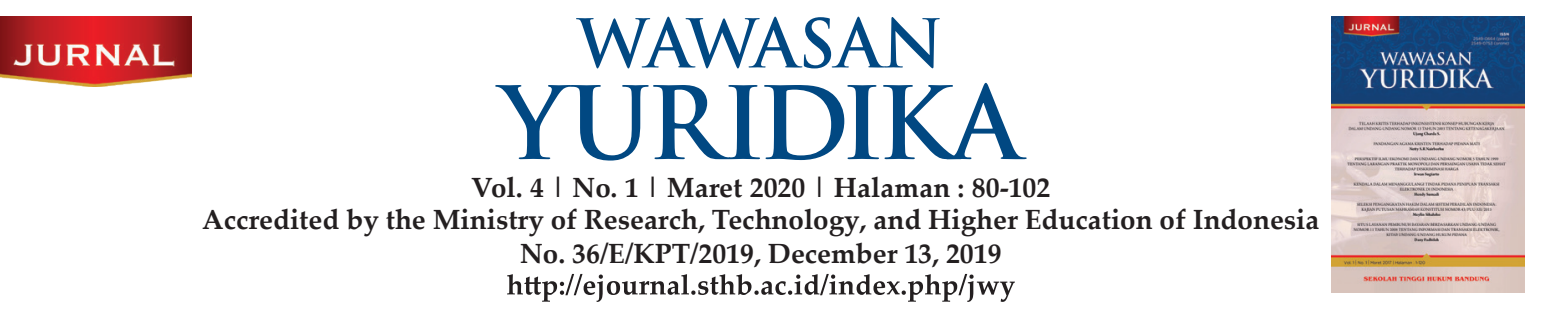

\title{
Pengawasan Publik terhadap Pejabat Publik yang Melakukan Tindakan Korupsi: Perspektif Hukum Administrasi
}

\author{
Nehru Asyikin \\ Pusat Kajian HAM dan Pelayanan Publik Aksa Bumi, Yogyakarta, Indonesia \\ $\square$ Corresponding Author: nehruasyikin1@gmail.com
}

\section{Info Artikel:}

DOI: $10.25072 /$ jwy.v4i1.316

Diterima: 3 Desember 2019 I Disetujui: 4 April 2020 IDipublikasikan: 20 April 2020

Kata Kunci:

Hukum Administrasi;

Korupsi; Pelayanan publik.

\begin{abstract}
Abstrak
Hukum administrasi negara menjadi kebutuhan untuk menjamin hak warga negara. Tujuan penelitian ini mengkaji pengawasan terhadap pejabat publik dari perspektif hukum administrasi kepada penyelenggara pelayanan publik. Penelitian ini bersifat deskriptif dengan jenis penelitian yuridis normatif. Pengumpulan data dengan studi pustaka, kemudian dianalisis secara kualitatif. Hasil Penelitian menunjukkan, pengawasan pelayanan publik memberikan kepastian hukum agar keputusan diterbitkan paling lama 10 hari, apabila tidak diterbitkan dianggap mengabulkan, dan apabila keputusan telah diterbitkan tetapi merugikan bisamemohonke Pengadilan Tata Usaha Negara. Tindakan malaadiministrasi bisa dilaporkan kepada Ombudsman. Dalam mengatasi korupsi, kolusi, dan nepotisme, meski diatur dalam Undang-Undang Nomor 20 Tahun 2001, tetapi peraturan ini hanya mengawasi secara represif, seharusnya pengawasan dilakukan secara preemtif oleh atasan dan preventif oleh aparat pengawasan intern pemerintah (APIP) sebelum terjadi kerugian negara.
\end{abstract}

Keywords:

Administrative Law;

Corruption; Public Services.

\begin{abstract}
The law of State administration becomes the need to guarantee citizen rights. The purpose of this study examines supervision from the perspective of administrative law to public service organizers. This research is a descriptive research with normative juridical research. Data collected with the study of libraries, then analyzed qualitatively. The results of the study show, supervision of public services provides legal certainty that the decision is issued for a period of 10 days, if unpublished is deemed to be granted, and if the decision has been published but adverse can apply to the State Administration Court. The act of Maladiministration can be reported to the Ombudsman. In overcoming corruption, collusion, and nepotism, although stipulated in the Law Number 20 of 2001, but this regulation only supervises repressive, should supervision be carried out preemptively by superiors and preventive by government internal supervision (APIP) before the loss of state.
\end{abstract}




\section{A. PENDAHULUAN}

Sudah sering terjadi para pejabat sebagai penyelenggara pelayanan publik "terciduk" kasus korupsi. Operasi tangkap tangan yang menyeret para pejabat baik di provinsi maupun kabupaten menunjukkan jika praktik Korupsi, Kolusi, Nepotisme belum hilang dari tahun ke tahun. ${ }^{1}$ Kondisi birokrasi seperti ini disebabkan karena akses terhadap kekuasaan negara itu cenderung dimiliki oleh para pejabat, pengelolaan kekayaan negara, dan semacamnya. Aktor korupsi juga bisa dilakukan oleh pihak luar yang berkolusi dengan penguasa kekuasaan tersebut. Dalam pengertian ini, korupsi juga bisa melibatkan kejadian penyuapan dan pemerasan. Hasil survei perilaku anti korupsi (SPAK) 2019, menunjukkan: (1) persentase masyarakat yang mengetahui adanya biaya resmi pada pelayanan publik kurang dari 70 persen; (2) masih adanya masyarakat yang membayar melebihi ketentuan ketika mengakses pelayanan publik; (3) sebagian besar pembayaran yang melebihi ketentuan terjadi sesudah pelayanan selesai; dan (4) sebagian besar pembayaran yang melebihi ketentuan terjadi dalam bentuk uang. ${ }^{2}$
Hal ini terjadi karena ada beberapa sikap masyarakat yang menganggap wajar beberapa kebiasaan dilingkup publik: pertama, memberi uang atau barang dalam penerimaan PNS itu dianggap wajar dengan persentase capai 29,94 persen. Padahal tahun sebelumnya persentasenya hanya 10,62 persen dari keseluruhan kepala rumah tangga yang disurvei. Kedua, memberi uang kepada polisi dalam pengurusan STNK, SIM, SKCK naik dari sebelumnya 24,52 persen menjadi 26,88 persen. Lalu ketiga, masyarakat yang menganggap wajar memberi uang saat pilkada atau pilkades juga meningkat dari 19,08 persen menjadi 21,34 persen. Keempat, survei juga menyebut masyarakat menganggap wajar jika para pendidik menerima hak eksklusif agar buah hatinya diterima bersekolah di sekolahnya mendidik. Ini naik tipis dari 27,99 persen manjadi 29,66 persen. Lalu memberi uang kepada petugas urusan administrasi juga naik. ${ }^{3}$

Oleh karena itu, upaya mewujudkan sistem rezim yang bersifat berkedaulatan, maka pemerintah harus mengubah sistem penyelenggaran pemerintahan dalam pelayanan kepada masyarakat sebagai bagian citacita perbaikan dari tahun 1998 agar

1 Tim Badan Pengawas Keuangan dan Pembangunan, “Warta Pengawasan Kawal Akuntabilitas Dan Pembangunan Mungkinkah APIP Efektif," Warta Pengawasan (Jakarta Timur, 2017), hlm. 3.

2 Badan Pusat Statistik, "Indeks Perilaku Anti Korupsi 2019” (Jakarta, 2019), hlm. 6.

3 Liputan6.com, “Indeks Perilaku Anti Korupsi Indonesia 2019 Meningkat,” https://www.liputan6. com/bisnis/read/4063890/indeks-perilaku-anti-korupsi-indonesia-2019-meningkat, diakses 27 Maret 2020. 
membentuk sistem pelayanan yang baik dan menjadi evaluasi bagi penyelenggara pemerintah dalam perombakan pola pemerintahannya. ${ }^{4}$

Tidak bisa dipungkiri jika hukum administrasi menjadi kebutuhan tidak hanya bagi pemerintah, tetapi kebutuhan masyarakat majemuk yang terus mengalami perkembangan yang harus dilayani oleh pemerintah. Sedangkan pada tatanan praktik, korupsi, kolusi, dan nepotisme (KKN) selalu saja menjadi penghambat kelancaran layanan publik, sehingga keinginan menciptakan sistem pemerintahan yang bersih atau good governance seperti didambakan akan menjadi sulit untuk terealisasi.

Sebetulnya, konsep good governance memiliki kandungan normatif dan karena itu terdapat referensi untuk menggunakan kepemerintahan yang baik. Pertimbangan bahwa good governance lebih dekat dengan pemerintahan dan juga hukum administrasi, serta makna fungsional dalam kata kepemerintahan yangbaik tersebutmenunjukkanaktivitas pemerintah dalam penyelenggaraan fungsinya yang tidak hanya merujuk pada aktivitas-aktivitas publik, tetapi juga aktivitas-aktivitas privat. ${ }^{5}$

Sedangkan pada pelayanan publik, dikenal teori negara kesejahteraan, karena tugas pemerintah dalam menjalankan roda pemerintahan menjadi bertambah luas sejak negara turut aktif dalam kehidupan bermasyarakat (perekonomian). Negara bertindak sebagai penyelenggara kesejahteraan umum. Secara teoretis, negara yang mempunyai tujuan utama mewujudkan kesejahteraan rakyat merupakan negara yang bertipe kesejahteraan (walfare state type). ${ }^{6}$

Hal ini setiap menjalankan tugasnya itu, hukum administrasi terlibat aktif mengawal dan memberi kepastian atas tindakannya tidak menyalahi aturan dan jaminan hak asasi warga negara, dan harus membedakan antara kepentingan negara "administrasi negara" yang memangku kebutuhan setiap warga negara. $^{7}$

Tujuannya agar birokrasi dalam setiap urusan warga negaranya dapat dilakukan dengan mudah, cepat, dan tanpa biaya yang lebih banyak agar

4 Tedi Sudrajat, "Perwujudan Good Governance Melalui Format Reformasi," Dinamika Hukum 9, No. 2 (2009): 118-125, hlm. 118.

5 Made Gde Subha Karma Resen, "Pengaturan Badan Usaha Miliki Daerah Berdasarkan Bood Governance Dan Good Corporate Governance', Disertasi Kementerian Riset, Teknologi Dan Pendidikan Tinggi Universitas Gadjah Mada Fakultas Hukum" (Yogyakarta: Gadjah Mada, 2015), hlm. 42.

$6 \quad$ Ibid., hlm. 22.

7 Sjahran Basah, Eksistensi Dan Tolak Ukur Badan Peradilan Administrasi Di Indonesia (Bandung: Alumni, 2014), hlm. 3. 
terhindar dari praktik KKN, terkhusus di dalam administrasi pemerintahan. Selain itu, diharapkan agar terwujudnya proses tata kelola pemerintahan yang transparan atau kejelasan mengenai proses penyelenggaraan sesuai dengan prosedur dan tidak lupa pula setiap kebijakan harus berdasarkan hukum tertulis, meskipun tidak tertulis, namun bisa dipertanggungjawabkan. ${ }^{8}$ Di sisi lain, pejabat pemerintahan berkewajiban mematuhi asas-asas umum pemerintahan yang layak (AAUPL), dan setiap menyelenggarakan administrasi negara wajib menjalankan AAUPL. Hal ini karena, saat ini penormaannya dicantumkan di dalam UndangUndang Nomor 30 Tahun 2014 tentang Administrasi Pemerintahan (selanjutnya disebut UU No. 30 Tahun 2014). Secara terperinci pada Pasal 10 UU No. 30 Tahun 2014, disebutkan AAUPL meliputi asas sebagai berikut: (1) Kepastian hukum; (2) Kemanfaatan; (3) Ketidakberpihakan; (4) Kecermatan; (5) Tidak menyalahgunakan kewenangan; (6) Keterbukaan; (7) Kepentingan umum; dan (8) Pelayanan yang baik. ${ }^{9}$
Sehingga keberadaan hukum administrasi dalam menciptakan good governance di Indonesia menjadikan keberadaannya sebagai aspek terpenting. Pemerintah memberikan pelayanan publik dapat memberikan keadilan, kepastian, dan kemanfaatan agar sesuai yang diharapkan berdasarkan peraturan perundang-undangan, namun hal ini masih menimbulkan pertanyaan, bagaimanakah peran hukum administrasi terhadap pengawasan di bidang pelayanan publik dan bagaimanakah peran hukum administrasi dalam mengatasi permasalahan KKN di Indonesia.

Memandang pada riset terdahulu, dalam penulisan ini terdapat 3 (tiga) hasil riset berbeda dengan riset yang penulis lakukan. Pertama, Tedi Sudrajat mengenai "Perwujudan Good Governance Melalui Format Reformasi Birokrasi Publik Dalam Perspektif Hukum Administrasi Negara,"10 Kedua, Nurul Laili Fadhilah mengenai "Urgensitas Ombudsman Dalam Pengawasan Pelayanan Publik,"11 dan ketiga, Isnawati mengenai "Perspektif Hukum Dalam Pengawasan Pengelolaan Keuangan Daerah."12 Berdasarkan hasil

S.F Marbun, Peradilan Administrasi Negara Dan Upaya Administrasi Di Indonesia (Yogyakarta: Liberty Offset, 1997), hlm. 337.

9 S.F. Marbun, Asas-Asas Umum Pemerintahan Yang Layak (Yogyakarta: FH UII Press, 2014), hlm. 60.

10 Tedi Sudrajat, op.cit., hlm. 124.

11 Nurul Laili Fadhilah, “Urgensitas Ombudsman Dalam Pengawasan Pelayanan Publik," Jurnal Pendidikan Pancasila Dan Kewarganegaraan 28, No. 2 (2015): 130-136, hlm. 135.

12 Isnawati, "Perspektif Hukum Dalam Pengawasan Pengelolaan Keuangan Daerah," Jurnal Ilmu Hukum Dan Sosial 29, No. 2 (2013): 95-108, hlm. 106. 
riset sebelumnya, meskipun hampir sama dalam penggunaan konsep good governance dan menekankan pada pengawasan, namun pada riset ini lebih memfokuskan pada pengawasan publik yang dilakukan oleh publik itu sendiri (pengawasan eksternal) atas wadah pengaduan yang diberikan hukum administrasi di dalam subsitemnya, serta pengawasan korupsi di Indonesia perspektif hukum administrasi atas tindakan pemerintah karena wewenangnya merugikan masyarakat dan negara. Penelitian inibertujuan untuk mengetahui peran hukum administrasi sebagai pengawas tindakan pemerintah dalam melakukan pelayanan publik dan sekaligus sebagai norma yang membatasi tindakan pemerintah agar tidak melakukan tindakan penyalahgunaan wewenang yang berpotensi korupsi dalam penyelenggaraan pemerintah.

\section{B. METODE PENELITIAN}

Pada penelitian ini menggunakan jenis penelitian normatif, sedangkan pendekatan pada penelitian ini dilakukan dengan melakukan pendekatan yuridis atau peraturan perundangundangan. Data yang dipakai ialah data sekunder dengan memanfaatkan bahan-bahan hukum berupa bahan hukum primer, sekunder dan tersier dengan memfokuskan pada kajian peran hukum administrasi di bidang pelayanan publik dan peran hukum administrasi dalam permasalahan $\mathrm{KKN}$ di Indonesia. Pengumpulan data yaitu studi pustaka yang dilakukan dengan menghimpun dan menganalisis hasil penelitian, undang-undang dan buku hukum, kemudian data yang terhimpun dianalisis secara kualitatif untuk memberikan gambaran atas kajian yang sudah dilakukan.

\section{HASIL DAN PEMBAHASAN \\ 1. Peran Hukum Administrasi terhadap Pengawasan di Bidang Pelayanan Publik}

Pada dasarnya, pemerintah selalu diikutsertakan dalam setiap urusan warga negaranya, terutama yang berhubungan dengan tertib administrasi. Hampir semua kegiatan masyarakat selalu bersentuhan dengan pemerintahan, karena dalam bidangbidang kehidupan administrasi baik di pusat ataupun di daerah masyarakat selalu memiliki kepentingan seperti mencari pekerjaan, perekonomian dan lain-lain. ${ }^{13}$ Oleh karenaitu, meningkatnya kualitas dan kuantitas tugas-tugas dari penyelenggara pemerintah memiliki

13 S.F. Marbun, Hukum Adminsitrasi Negara I (Administrative Law I), Ed. Revisi (Yogyakarta: FH UII Press, 2018), hlm. 4. 
konsekuensi agar dihadirkannya sistem pengawasan dengan sungguh-sungguh dan optimal demi memperbaiki praktik malaadministrasi oleh oknum pejabat yang berwenang. ${ }^{14}$

Maka yang diperlu diperhatikan ialah keberadaan public service (pelayanan publik) di dalam birokrasi untuk memenuhi kebutuhan masyarakat, ${ }^{15}$ sehingga paling tidak, di dalam penyelenggaraan pemerintah harus pula diperhatikan kewajiban pemerintah yang sudah sesuai atau belum dalam pelaksanaannya. Ombudsman Indonesia menjelaskan tentang malaadministrasi sebagai berikut:

"Adapun pengertian malaadiministrasi secara umum adalah prilaku yang tidak wajar (termasuk penundaan pemberian pelayanan), tidak sopan dan kurang peduli terhadap masalah yang menimpa seseorang disebabkan oleh penyalahgunaan kekuasaan, termasuk penggunaan kekuasaan secara semenamena atau kekuasaan yang digunakan untuk perbuatan yang tidak wajar, tidak adil, intimidatif atau diskriminatif, dan tidak patut didasarkan seluruhnya atau sebagian atas ketentuan undang-undang atau fakta, tidak masuk akal, atau berdasarkan tindakan unreasonable, unjust, oppressive, improper dan deskriminatif. Malaadminsitrasi dapat merupakan perbuatan, sikap maupun prosedur dan tidak terbatas pada hal-hal administrasi atau tata usaha saja. ${ }^{16}$

Atas tindakan-tindakan pejabat pemerintah atau aparatur yang bertugas melayani publik yang masuk ke dalam kategori malaadministrasi, pengawas internal dapat mengawasi setiap pelayanan publik yang diselenggarakan, yakni dilakukan oleh pimpinannya dalam suatu inspektorat. Mengutip George R Terry, model pengawasan yang ditawarkan meliputi: a) Mengoptimalkan hasil yang menjadi tujuan bersama; b) mengoptimalkan pemakaian dana, tenaga, material dan waktu untuk di buat hemat; c) mengukur pelaksanaan pekerjaan penilaian dapat dilakukan melalui laporan (lisan dan tertulis, atau dengan inspeksi secara langsung; d) mengkomparasikan antara pengawasan yang sudah dilakukan dengan hasil di lapangan, dan mengoreksi agar menjadi bahan evaluasi; e) hasil eveluasi kemudian menjadi dasar untuk memperbaiki bagian-bagian yang harus segera diperbaiki atau yang belum penting

14 Soehartono, "Eksistensi Asas-Asas Umum Pemerintahan Yang Baik Sebagai Dasar Pengujian Keabsahan Keputusan Tata Usaha Negara Di Peradilan Tata Usaha Negara," Yustisia Jurnal Hukum 1, No. 2 (2012): 180-193, https://doi.org/10.20961/yustisia.v1i2.10644, hlm. 184.

15 Jawade Hafidz, "Malfungsi Han Dan Upaya Melakukan Rekonstruksi Sistem Hukum Yang Ada Menuju Hukum Yang Melayani," Jurnal Hukum 28, No. 2 (1970): 841-860, https://doi.org/https://doi. org/10.20961/yustisia.v1i2.10644, hlm. 847-848.

16 Ridwan HR, Diskresi Dan Tanggung Jawab Pemerintah (Yogyakarta: FH UII Press, 2014), hlm. 209. 
untuk diperbaiki dari hasil pengawasan tersebut. ${ }^{17}$ Selain itu, pengawasan eksternal dilakukan oleh masyarakat, Ombudsman, Dewan Perwakilan Rakyat, dan Dewan Perwakilan Rakyat Daerah. ${ }^{18}$ Kemudian, Peradilan Tata Usaha Negara memiliki peran dalam mengawasi pejabat pemerintahan atas perbuatan malaadministrasi yang merugikan rakyat. ${ }^{19}$ Untuk menjaga kemungkinan terjadinya kesalahan yang berakibat melanggar hak masyarakat yang dilakukan pemerintah dalam melaksanakan tugas-tugas sosialnya, maka ditentukan adanya lembaga yang berwenang mengadili atas tindakan/ keputusan pejabat tersebut yang dimohonkan oleh masyarakat dan badan hukum perdata yang dirugikan. ${ }^{20}$

Sebab, berkenaan dengan hakhak dari masyarakat, termasuk badan usaha di dalamnya yang dimiliki oleh masyarakat. Antara pemerintah selaku pemerintah dengan pemerintah selaku administrasi negara mengambil keputusan dengan wewenang yang sama, yakni "wewenang kenegaraan" atau wewenang publik. Landasan dari tindakan yang diambil oleh administrasi negara tentunya berdasarkan pada ketentuan peraturan di dalam hukum administrasi negara (administratieve rechtsregels), sebagai dasar yang membenarkan tindakan itu secara hukum (juridische rechtsvaardiging), sesuai dengan konsep negara hukum. Peraturan hukum (rechtsregels) ini terkait dengan organisasi dari instansi administrasi negara (organische rechtsregels), dan mengenai fungsi-fungsi administrasi negara (functionele rechtsregels). ${ }^{21}$

Efektivitas fungsi Ombudsman sebetulnya dapat dilihat sejauh mana warga negara Indonesia memiliki pengetahuan dan faham alasan dibentuknya lembaga ini. Karena atas praktik-praktik penyelewengan oleh pejabat, kehadiran masyarakat sebagai ujung tombak untuk memberi laporan kepada Ombudsman.22 Hal ini disebabkan Ombudsman bergerak apabila ada laporan dari warga negara atau secara gamblang dijelaskan dalam Pasal 7 UU No. 37 Tahun 2008 tentang

17 Miftakhul Ulum Fatmawati dan Maisaroh, "Peranan Pengawasan Fungsional Dalam Sisitem Administrasi Negara Kesatuan Repubik Indonesia," Fakultas Ilmu Administrasi (Jakarta, 2019), https://doi.org/.1037//0033-2909.I26.1.78. hlm. 45-46

18 S.F. Marbun, Hukum Adminsitrasi II (Yogyakarta: FH UII Press, 2013), hlm. 23.

19 George R. Terry dalam Soehartono, loc.cit.

$20 \quad$ Ibid., hlm. 53.

21 Herman Herman, "Perlindungan Hukum Warga Negara Terhadap Tindakan Pemerintah Dalam Membuat Keputusan Administrasi Negara," Jurnal Komunikasi Hukum (JKH) 1, No. 1 (2015): 44-54, https://doi.org/10.23887/jkh.v1i1.5012, hlm. 44-45.

22 Ayu Desiana, "Reformasi Birokrasi Pemerintah Daerah Menuju Good Governance," Jurnal Manajemen Dan Pembangunan I, No. 1 (2014): 19-47, hlm. 44. 
Ombudsman Republik Indonesia, menjelaskan jika Ombudsman hanya menerima laporan meski hanya sebatas dugaan malaadministrasi. Kemudian atas dasar laporan tersebut, Ombudsman melanjutkan untuk menangani dugaan malaadministrasi di instansi terkait.

Laporan dapat dilakukan oleh siapapun yang merasakan langsung pelayanan publik maupun melihat langsung perbuatan yang diskriminatif atau meminta sejumlah uang di luar biaya administrasi, hal ini sejalan dengan Pasal 1 angka 5 UU No. 37 Tahun 2008 tentang Ombudsman Republik Indonesia, mengamanatkan jika pelapor ialah warga negara Indonesia/penduduk yang memberikan laporan kepada Ombudsman. ${ }^{23}$ Laporan masyarakat bisa dikatakan sebagai bentuk pengawasan pelayanan publik sebagai subjek dari penyelenggaraan layanan dari pemerintah.

Secara teori, hukum administrasi memberikan norma terhadap setiap perbuatan hukum pemerintah di bidang publik itu hampir selalu menggunakan instrumen hukum, yang di dalamya memuat sejumlah norma rujukan dan norma pengarah. Dalam hal ini, hukum administrasi memuat norma-norma hukum agar bisa dibaca dan dipahami oleh masyarakat ketika berhadapan dengan pemerintah, baik dalam rangka mempengaruhi atau memberi masukan kepada pemerintah dalam perbuatan pemerintahan (inspraak), maupun menggugat pemerintah yang menyimpang (bezwaar). ${ }^{24}$

Menurut Marbun S.F, pengetahuan atas norma-norma ketika berhadapan dengan pemerintah secara sederhana yang tepat digunakan untuk menguji hal di atas adalah asas asas umum pemerintahan yang baik, khususnya asas larangan penyalahgunaan jabatan. ${ }^{25}$ Sedangkan, untuk membedakan bidangbidang yang menjadi kewenangan pejabat pemerintah itu dapat dilihat bahwa hukum administrasi terdiri dari dua bagian, yaitu bidang khusus (bijzonder deel) yang berfokus pada penormaan saja, seperti hukum pajak, hukum kesehatan, hukum lingkungan. Kemudian bidang umum (algemen deel), lebih berfokus pada teorinya dan asasasas yang diberlakukan pada setiap aspek hukum administrasi. ${ }^{26}$

Oleh karena itu, kewenangan yang melekat pada pejabat atau fungsi

23 Pasal 1 angka 5, Undang-Undang Nomor 37 Tahun 2008 tentang Ombudsman Republik Indonesia.

24 Ridwan HR, Tiga Dimensi Hukum Adminsitrasi Dan Peradilan Adminstrasi (Yogyakarta: FH UII Press, 2009), hlm. 3.

25 Marbun, Hukum Adminsitrasi Negara..., op.cit., hlm. 135.

26 Arfan Faiz Muhlizi, "Reformulasi Diskresi Dalam Penataan Hukum Administrasi (Reformulation Of Discretion In The Arrangement Administrative Law)," Jurnal Rechtsvinding 1, No. 1 (2012): 93-111, hlm. 103. 
tersebut melekat kesinambungan dengan kewajiban, maka pemangku jabatan dapat bertindak atas nama jabatannya, ${ }^{27}$ sehingga pejabat yang diberikan kewenangan tersebut dapat melaksanakan tanggung jawabnya dan memberikan kepastian hukum serta perlindungan atas keputusannya. Adapun yang menjadi alasanalasannya sebagai berikut: masyarakat dan badan usaha/badan hukum menggantungkan kepentingannya pada keputusan pemerintah, semacam meminta surat izin untuk usaha atau perusahaannya. Karena alasan itu, perlu adanya kepastian dan jaminan hukum terhadap kepentingan tersebut, apalagi sering timbul perselisihan apabila ada intervensi dari pemerintah yang bersifat sepihak..$^{28}$

Selain izin, permohonan yang biasa dimohonkan oleh masyarakat adalah dispensasi. Dispensasi merupakan permohonan masyarakat agar dapat diberikan kebebasan agar tidak terikat dengan peraturan yang sudah dibuat oleh pemerintah. ${ }^{29}$ Kaitannya terhadap permohonan untuk dikeluarkannya keputusan dari warga negara dalam hal meminta izin atau dispensasi dirumuskan dalam Pasal 1 angka 3 UU
No. 5 Tahun 1986 tentang Peradilan Tata Usaha Negara yang diubah dengan Pasal 1 angka 9 UU No. 51 Tahun 2009 tentang Peradilan Tata Usaha Negara, oleh Pasal 87 telah diubah dengan memberikan makna baru dengan menambah tindakan pejabat tersebut harus faktual dan tertulis yang dikeluarkan pejabat pemerintah di tiga cabang kekuasaan, yaitu eksekutif, legislatif, yudikatif. Rujukan tindakan tersebut harus berdasarkan undangundang dan AAUPB. Kemudian sifatnya harus final dalam arti luas yang berakibat hukum. ${ }^{30}$ Sedangkan, pada huruf a penetapan tertulis ada penambahan tindakan faktual atau harus adanya perbuatan nyata, huruf b keputusan itu mencakup bukan hanya di lingkungan pemerintahan eksekutif, namun mencakup lingkungan pemerintahan legislatif dan yudikatif serta penyelenggara negara lainya.

Pada penormaan di dalam UU No. 5 Tahun 1986 tentang Peradilan Tata Usaha Negara menjelaskan, badan/pejabat tata usaha negara tidak mengeluarkan keputusannya, maka dianggap sudah menerbitkan surat keputusan berupa penolakan atau disebut sebagai keputusan fiktif negatif, menurut ketentuan Pasal 3 ayat (1) UU No. 5 Tahun

\footnotetext{
27 Marbun, Asas..., op.cit., hlm. 74.

28 Ridwan HR, Hukum Administrasi Negara, Ed. Revisi (Jakarta: RajaGrafindo Persada, 2017), hlm. 277.

29 Pasal 1 angka 19 dan angka 22, Undang-Undang Nomor 30 Tahun 2014 tentang Administrasi Pemerintahan.

30 Pasal 87, Undang-Undang Nomor 30 Tahun 2014 tentang Administrasi Pemerintahan.
} 
1986 menjelaskan pula masa waktu untuk diterbitkannya keputusan itu selama empat bulan, apabila waktunya tidak ditentukan dalam undangundang, namun waktu menunggu selama empat bulan tersebut jika sudah lewat waktu, maka dianggap pejabat tersebut menolak permohonannya. Sehingga dapat dilihat jika dalam penormaan terkait batas waktu tersebut, tidak memberikan kepastian hukum yang berdampak pada pelayanan publik tidak efisien, atau secara tidak langsung pemohon diwajibkan menunggu selama berbulan-bulan dan dihadapkan pada 2 (dua) pilihan, yaitu ditolak karena sikap diskriminatif atau diterima tapi dengan ketidakpastian batas waktu.

Ketidakpastian hukum tersebut, menurut Taufiqurokhman dan Evi Satispi menjabarkan, secara teori ada beberapa model dalam pelayanan publik. Pelayanan yang modelnya birokratis cocok untuk budaya masyarakat hirarkhis; pelayanan publik yang modelnya privatisasi cocok untuk budaya masyarakat individual (yang anti hirarkhis); pelayanan publik yang modelnya kolektif cocok untuk budaya masyarakat fatalis (yang mendukung budaya hirarkhis dan anti budaya individu); sedangkan pelayanan publik yang modelnya memerlukan pelayanan cepat dan terbuka cocok untuk budaya masyarakat egaliter (yang anti budaya hirarkhis, anti budaya individu dan anti budaya fatalis). Masalahnya sekarang, untuk masyarakat Indonesia dewasa ini tergolong dalam kategori budaya masyarakat yang mana? Masyarakat Indonesia saat ini sudah memasuki era budaya masyarakat egaliter; oleh karenanya bentuk pelayanan publik yang cocok adalah model pelayanan cepat dan terbuka. ${ }^{31}$

Perbandingan regulasi terkait batas waktu ini pun berbanding terbalik, sebab Pasal 53 UU No. 30 Tahun 2014 BAB IX mengenai Keputusan Pemerintah, menentukan batas waktu kewajiban bagi badan dan/atau pejabat pemerintahan agar ada penetapan keputusan (K.TUN), serta diberikan kepastian jangka waktu agar pejabat wajib segera melakukan suatu tindakan dalam rangka penyelenggaraan pemerintahan. Adapun keputusan dan/ atau tindakan dalam waktu paling lama 10 (sepuluh) hari kerja dari pertama permohonan diterima. ${ }^{32}$ Kemudian kepastian hukum dalam penormaan baru ini, jika pejabat yang dimaksud tidak melakukan tindakan konkret/ faktual atau tidak menerbitkan K.TUN

\footnotetext{
31 Taufiqurokhman dan Evi Satispi, Perkembangan Manajemen Pelayanan Publik Teori Dan Perkembangan Manajemen Pelayanan Publik, Ed. Pertama (Ciputat, Tanggerang Selatan: UMJ PRESS, 2018), hlm. 146.

32 Pasal 53, Undang-Undang Nomor 30 Tahun 2014 tentang Administrasi Pemerintahan.
} 
dianggap dikabulkan menurut hukum. ${ }^{33}$ Oleh karena itu, Pasal 53UU No. 30 Tahun 2014 telah menjamin kepastian hukum kepada warga masyarakat.

Hal ini karena, semua pemerintahan di dunia dihadapkan pada kebutuhan masyarakat yang harus dilayani dengan cepat dengan waktu yang jelas tanpa berbelit-belit dan ditunda-tunda, sehingga untuk memenuhi kebutuhan masyarakat itulah pemerintah wajib memberikan pelayanan yang lebih efisien. Tantangan yang dihadapi oleh pemerintah ini memberikan kritik agar pemerintah tidak hanya memberikan pelayanan apa adanya tetapi harus melayani dengan kualitas dan mutu yang tinggi. ${ }^{34}$

Sebagaimana pengaturannya terdapat pada Pasal 10 UU No. 30 Tahun 2008 tentang Administrasi Pemerintahan yang meliputi asas kepastian hukum, kemanfaatan, ketidakberpihakan, kecermatan, tidak menyalahgunakan kewenangan, keterbukaan, kepentingan umum, dan pelayanan yang baik yang menjadi kewajiban penyelenggara negara untuk mengikutinya. Karena itu, paling tidak semua urusan tata pemerintahan berupa kebijakan publik, baik yang berkenaan dengan pelayanan publik maupun pembangunan di daerah harus diketahui publik.

Keterbukaan itu meliputi, substansi dan argumen setiap kali pejabat pemerintah menerbitkan suatu kebijakan yang diperuntukkan bagi masyarakat. Maka akses untuk mengetahui maksud dan tujuan dari substansi kebijakan itu wajib diberikan kepada masyarakat agar ditanggapi. Demikian pula segala bentuk aktivitas-aktivitas pengemban kebijakan wajib diketahui oleh masyarakat dan mudah di akses oleh masyarakat, ${ }^{35}$ sehingga penyelenggara pemerintahan memiliki kewajiban untuk selalu menginformasikan dan mempermudah akses mendapatkan informasi tersebut. Dalam hukum administrasi, keterbukaan untuk memperoleh informasi ini meliputi keterbukaan sidang atau pertemuan (openbaarheid van vergadering), keterbukaan prosedural (openbaarheid van procedures), dan keterbukaan mengakses dokumen (openbaarheid van register). ${ }^{36}$

33 Laica Marzuki, "Pemberlakuan Undang-Undang Nomor 30 Tahun 2014 Tentang Administrasi Pemerintahan Dalam Konteks Perkembangan Kompetensi Peradilan Tata Usaha Negara RI," Implementation Science 39, (Jakarta, 2017), https://doi.org/10.4324/9781315853178, hlm. 5.

34 Jazim Hamidi, "Paradigma Baru Pembentukan Dan Analisis Peraturan Daerah (Studi Atas Perda Pelayanan Publik Dan Perda Keterbukaan Informasi Publik)," Jurnal Hukum Ius Quia Iustum 18, No. 3 (2011): 336-362, https://doi.org/10.20885/iustum.vol18.iss3.art3., hlm. 350.

35 BPHN, “Laporan Akhir Tim Kompendium Bidang Hukum Pemerintah Yang Baik,” 2007, hlm. 27.

36 Ridwan HR, "Arti Penting Asas Keterbukaan Dalam Penyelenggaraan Pemerintahan Yang Bebas Dari Korupsi, Kolusi, Dan Nepotisme (KKN)." Jurnal Hukum IUS QUIA IUSTUM 11, No. 27 (16 September 2004), hlm. 56. 
2. Peran Hukum Administrasi dalam Mengatasi Permasalahan Korupsi, Kolusi, dan Nepotisme di Indonesia

Pemerintahan suatu negara dipandang baik atau kurang baik dalam melayani masyarakat sebetulnya bukan pada manajemen birokrasinya yang belum mapan, ada kalanya pada wilayah pengambilan tindakan para pejabat cenderung korup. Hal ini mengakibatkan kerugian negara maupun dalam bidang pelayanan, pejabat cenderung lebih mengutamakan kerabat maupun yang berani me "lobby" agar urusannya dapat cepat selesai. Biasanya hal ini ini terjadi karena posisinya pernah sebagai simpatisan atau pendukung rezim yang berkuasa saat itu, sehingga hal ini menimbulkan hak agar diberikan kemudahan atas kepentingankepentingan yang menguntungkannya, alasan ini yang menjadi asal mula munculnya KKN. ${ }^{37}$

Menurut United Nations Development Programme (UNDP) dalam Nur Rohim Yunus, kekhususan good governance, sebagai berikut: (a) Participation (partisipasi); masyarakat memiliki hak bersuara dalam pembentukan keputusan secara langsung baik mewakili lembaga atau organisasinya; (b) Rule of law (berbasis peraturan); kerangka hukum harus sesuai dengan amanat konstitusi atau undang-undang sebagai amanat untuk memberikan rasa adil, dan persamaan hak terutama menjunjung tinggi HAM; (c) Transparancy (terbuka); transparansi yang diberikan merupakan hak masyarakat agar mudah mengakses segala informasi apapun di internal pemerintah; d) Responsiveness (responsif); setiap pelaksana kegiatan pelayanan publik harus memiliki sifat menanggapi dan tanggap atas kebutuhan masyarakat yang didasari dari etika profesi dan etika individu penyelengara; (e) Consensus orientation (orientasi konsensus); para pejabat harus memperhatikan dan memahami batasan kewenangannya, terutama pada pengambilan kebijakan, yakni kebijakan mana yang harus di bentuk harus melibbatkan partisipasi masyarakat, dan kebijakan yang menyangkut teknis yang boleh ditentukan secara individu menurut jabatannya; (f) Accountability (akuntabel); keputusan yang dibuat oleh pejabat pemerintah memiliki beban tanggung jawab kepada masyarakat, pengawasan menjadi kunci utama evaluasi dan kontrol dari pelaksanaan standard operating procedure (SOP) yang sudah ditetapkan. ${ }^{38}$

37 Bagir Manan, Menyongsong Fajar Otonomi Daerah (Yogyakarta: Pusat Studi Hukum Fakultas Hukum Universitas Islam Indonesia, 2001), hlm. 113.

38 Nur Rohim Yunus, "Menciptakan Good and Clean Government," Nur El-Islam 3, No. 1 (2016): 143175, hlm. 150-153. 
Berhubungan dengan itu, partisipasi dan transparansi bertujuan untuk menghindari kerugian-kerugian masyarakat di masa mendatang yang tidak tepat sasaran, hal ini karena penyalahgunaan kewenangan atau dalam administrasi pemerintah dijelaskan pula di dalam Pasal 17 dan Pasal 18 UU No. 30 Tahun 2014, secara terperinci menjelaskan bahwa karakteristik agar tidak menyalahi wewenangnya, maka pejabat tersebut tidak boleh melampaui wewenang, melampaui masa jabatannya, melampaui batas wilayah berlakunya kewenangan tersebut, dan menyelahi undangundang.

Sedangkan, istilah mencapuradukkan wewenang atas keputusan dan/ atau tindakan karena menjalankan kewenangan di luar dari cakupan bidang yang dipangkunya, berbeda tujuan dari wewenang itu diberikan karena tanpa dasar wewenang dan menyalahi putusan pengadilan yang telah inkrah. ${ }^{39}$

Pada penormaan di dalam UU No. 30 Tahun 2014 di atas memiliki hubungan yang saling berkaitan dengan Pasal 2 ayat (1) UU No. 31 Tahun 1999 tentang Pemberantasan Tindak Pidana Korupsi. Pasal ini sering digunakan untuk menjerat perbuatan korupsi, karena rumusannya yang luas dan mengandung pengertian sangat abstrak. Rumusan pengertian yang luas dan abstrak tersebut mengandung segi positif dan negatif. Segi positif dapat digunakan dengan mudah menjerat perbuatan korupsi, sedangkan segi negatif dapat mengurangi kepastian hukum karena dapat membuka peluang untuk menggunakannya secara serampangan. ${ }^{40}$

Pada pasal yang lain, yaitu Pasal 3UU No. 31 Tahun 1999 tentang Pemberantasan Tindak Pidana Korupsi, penyalahgunaan wewenang atau memberikan keuntungan kepada pihak lain, baik perorangan maupun perusahaan yang secara tidak langsung pejabat tersebut mendapatkan keuntungan bagi dirinya dan berakibat merugikan negara, maka pasal ini memberikan hukum pidana penjara. ${ }^{41}$

Mengacu pada penormaan di atas, pengawasan yang tertulis padaUU No. 31 Tahun 1999, lebih kepada pengawasan represif atau sudah terjadinya suatu tindakan korupsi oleh pejabat pemerintahan. Seharusnya, pengawasan yang lebih efisien dan efektif manakala kerugian itu bisa diantisipasi seharusnya dimaksimalkan pengawasan preventif, yaitu pengawasan yang dilakukan oleh atasan karena lebih mengetahui bawahannya dan dengan aparat

\footnotetext{
39 Marzuki, op.cit., hlm. 8.

40 Marbun, Hukum Adminsitrasi Negara I...op.cit., hlm. 86.

41 Ibid.
} 
pengawas internnya sebelum terjadinya kerugian negara akibat tindakan korup tersebut atau pada saat diketahui adanya kebocoran keuangan negara, sehingga kerugian dapat terhindarkan. Sedangkan pengawasan dapat dilakukan dengan preemtif yaitu dengan memberikan himbauan atau peringatan tegas dari atasan dalam suatu instansi atau lembaga yang tujuan untuk mencegah terjadinya tindakan korup.

Berhubungan dengan penyalahgunaan jabatan tertuang pada Pasal 5 UU No. 20 Tahun 2001 tentang Perubahan atas UU No. 31 Tahun 1999 tentang Pemberantasan Tindak Pidana Korupsi yang dalam hal ini berkaitan dengan Pasal 17 UU No. 30 Tahun 2014 tentang Administrasi Pemerintahan pada bagian larangan penyalahgunaan wewenang. Namun, pada penormaan Pasal 5 ayat (1) huruf a dan huruf b sebetulnya larangan dimaksud ditujukan kepada masyarakat sipil, baik perseorangan (natuurlijke persoon), seseorang yang mewakili badan hukum (rechts persoon) atau yang mewakili badan usaha seperti persekutuan komanditer (CV) yang memiliki kepentingan terhadap pejabat yang diberi wewenang tersebut. Larangan pada Pasal 5 ayat (1) tersebut terdapat ancaman pidana dan/atau denda bagi warga negara untuk tidak diperbolehkan bagi seseorang itu menjanjikan dan memberi sesuatu hal agar pegawai negeri tersebut menyelahi wewenangnya. Adapun bagi seseorang yang memiliki hubungan dekat dengan pegawai negeri tersebut, maka larangan ini berlaku bagi dirinya. ${ }^{42}$

Tetapi penormaan ini, tidak hanya memberikan sanksi berat kepada masyarakat tetapi juga bagi pegawai negeri yang berdasarkan wewenannya dalam penyelenggaraan pelayanan publik tersebut. ${ }^{43}$ Maka dalam hal ini tidak hanya yang memberi atau menjanjikan sesuatu yang terkena sanksi pidana, tetapi kedua-duanya menjadi subjek hukum yang dapat dipidana berdasarkan UU No. 20 Tahun 2001 tersebut. Penyalahgunaan jabatan menjadi norma yang imperatif untuk menjamin terselenggaranya pemerintahan untuk melayani masyarakat.

Berkaitan di atas, Kranenburg adalah seorang ahli hukum dari Jerman yang menggagas teori negara kesejahteraan (welfare state). Menurutnya, tujuan negara ada 3 yaitu sebagai berikut: (1) Pemerintah bukan sekadar menjaga keamanan, ketertiban tetapi memperjuangkan warga negaranya agar

\footnotetext{
42 Pasal 5 ayat (1) huruf a dan huruf b, Undang-Undang Nomor 20 Tahun 2001 tentang Perubahan atas Undang-Undang Nomor 31 Tahun 1999 tentang Pemberantasan Tindak Pidana Korupsi.

43 Ibid.
} 
sejahtera dan makmur; (2) Pemerintah harus menunjukan keadilan dalam setiap tindakan atau kebijakan yang berkesamaan kedudukannya dan tidak membeda-bedakan. ${ }^{44}$

Banyak perbuatan pejabat administrasi negara yang dilakukan dengan keputusan administrasi negara, di kemudian hari dinyatakan sebagai tindak pidana korupsi karena ditemukan adanya bukti bahwa keputusan administrasi negara tersebut menimbulkan kerugian bagi perekonomian atau keuangan negara. Batasan yang tegas apakah seorang pejabat administrasi negara yang didakwa melakukan tindak pidana korupsi dapat dipertanggungjawabkan adalah kondisi atau faktor objektif di lapangan yaitu apakah pejabat tersebut melakukan tindakan yang sesuai dengan kewenangannya, mengambil kebijakan atau senyatanya bertentangan dengan kewenangannya berdasarkan peraturan perundang-undangan yang berlaku. ${ }^{45}$

Sedangkan perbuatan hukum yang dilakukan pejabat pemerintah tersebut dapat ditinjau melalui pengawasan, menurut Paulus E Lotulung dikutip Victorianus, pengawasan di dalam hukum administrasi Negara terdiri dari beberapa hal, antara lain: 1) Dilihat dari aspek kedudukan suatu badan atau organ yang menjalankan control, dibedakan antara jenis control eksternal dan control internal. Control intern berarti dijalankan secara organisatoris/structural di wilayah internalnya; kemudian control ekstern dijalankan organistaoris/structural berada di wilayah luar pemerintah yang dilakukan oleh lembaga yang diberi tugas dan fungsi mengawasi pemerintahan itu. 2) Dilihat dari aspek tempo atau waktu pelaksanaan control itu dijalankan, maka jenisnya dipisah antara control apriori dan control aposteriori. Control apriori dilakukan sejak dini sebelum diterbitkannya keputusan atau ketetapan pemerintah; sedangkan control aposteriori terjadi bila pasca diterbitkannya keputusan atau ketetapan pemerintah. 3) Dilihat dari objek pengawasan, dibedakan antara control dari segi hukum/rechtmatigheid (pertimbangan hukumnya saja/segi legalistas), yaitu perbuatan pemerintah; sedangkan doelmatigheid (dari segi kemanfaatan) untuk menguji apakah tindakan itu dibenarkan atau tidak. ${ }^{46}$

44 Irawan Harimurti, Jaminan Terhadap Pemenuhan Hak Tenaga Kerja Kaitannya Dengan Legalisasi Sistem Pekerja Kontrak Untuk Jangka Waktu Jangka Pendek (Outsourcing) (Analisis Yuridis Terhadap UndangUndang Nomor 13 Tahun 2003 Tentang Ketenagakerjaan), Tesis Pada Program Magister Ilmu Hukum Program Pascasarjana Universitas Sevelas Maret, (Surakarta: USM, 2010), hlm. 16.

45 Hamzar Nodi, "Pertanggungjawaban Pejabat Administrasi Negara Dalam Hal Terjadinya Kerugian Pada Keuangan Negara Dalam Kasus Tindak Pidana Korupsi," Jurnal Ilmu Hukum Riau 3, No. 1 (2012), hlm. 1.

46 Paulus E Lotulung dalam Victorianus MH Randa Puang, Hukum Pendirian Usaha Dan Perizinan (Yogyakarta: DEEPUBLISH, 2015), hlm. 64. 
Pada dimensi lain, badan/organ yang mengontrol pada wilayah intern menurut hukumnya (rechtsmatigheid) dilaksanakan oleh aparat pengawasan intern pemerintah (APIP), menurut mekanismenya berdasarkan Pasal 20 UU No. 30 Tahun 2014 tentang Administrasi Pemerintahan. Pengawasan internal yang khusus memeriksa suatu tindakan yang dikeluarkan pejabat yang berasal dari wewenangnya diperiksa pada 3 (tiga) hal pokok, (1) tidak terdapat kesalahan; (2) terdapat kesalahan administratif; atau (3) terdapat kesalahan administratif yang menimbulkan kerugian keuangan negara. Pada kesalahan administratif, terjadi karena kesalahan prosedural yang dilakukan atau pada proses administrasi yang mencakup seluruh kegiatan dan penerapan aturan dalam mengeluarkan tindakan administratif terindikasi melakukan tindakan yang disengaja karena pengaruh untuk menguntungkan dirinya atau pengaruh seseorang dengan memanfaatkan jabatannya tersebut. Kemudian bentuk tindak lanjut dari APIP apabila terjadi kesalahan administratif, maka hasil pemeriksaan dikembalikan kepada pejabat administrasi tersebut yang mengeluarkan untuk diperbaiki menurut prosedur dan aturan berdasarkan undang-undang apabila memang tidak ada kerugian negara. Sedangkan apabila ada indikasi merugikan negara, maka APIP dalam hal ini memberikan kesempatan kepada pejabat administrasi selama 10 hari kerja sejak hasil pemeriksaan kesalahan administrasi dilakukan untuk mengembalikan keseluruhan total kerugian keuangan negara atau kekayaan milik negara.

Lebih mudahnya berdasarkan penjelasan pada bagian sebelumnya dapat dilihat dalam bagan sebagai berikut:

\section{Tabel. 1 Pengawasan dalam Hukum Administrasi Negara}

\begin{tabular}{lll}
\hline \multicolumn{1}{c}{$\begin{array}{c}\text { Badan/Organ yang } \\
\text { Mengontrol }\end{array}$} & \multicolumn{1}{c}{ Waktu Pelaksanaan } & \multicolumn{1}{c}{ Objek Pengawasan } \\
\hline Kontrol Intern & Apriori & Rechtmatigheid \\
Kontrol Ekstern & Aposteriori & Doelmatigheid \\
\hline
\end{tabular}

Sumber Tabel: Victorianus MH Randa Puang dalam Buku Hukum Pendirian Usaha dan Perizinan.

Akan tetapi, jika dihubungkan pada control apriori menurut waktu yang dilakukan oleh APIP, menurut fungsi dan pengawasannya, maka kontrol APIP menurut Pasal 20 UU No.
30 Tahun 2014 tentang Administrasi Pemerintahan sama sekali bukan wilayah kewenangannya. Hal ini karena apriori dilihat dari waktu pelaksanaan kebijakan itu sudah dilaksanakan 
dan menurut fungsinya, APIP hanya memiliki kontrol setelah kebijakan itu dilaksanakan dan ditemukan kerugian negara yang disebabkan oleh kesalahan administrasi.

Terlihat jika sebetulnya keberadaan APIP sebagai pengawas internal, di mana tugasnya untuk mengetahui dari awal dugaan korupsi atas tindakan dan/atau keputusan pejabat tersebut, masih mengalami kegagalan dan banyak hambatan. Alasannya karena masih banyak terjadi kasus korupsi yang dilakukan oleh pejabat penyelenggara pemerintahahan. ${ }^{47}$

Secara teori,pada internal control setiap unit kerja harus bersifat in build, yaitu pada saat terdapat penyimpangan, sejak awal sudah diketahui dan secepat mungkin di perbaiki. Penyebab internal control di setiap unit tidak berfungsi hal ini disebabkan oleh pejabat atau pegawai terkait ber-KKN. ${ }^{48}$

Solusi dari kendala keberadaan internal control yang dilaksanakan oleh APIP, yaitu pengawasan intern (APIP) harus dimasukkan ke dalam hukum positif (undang-undang) menjadi keinginan masyarakat dan kebutuhan pemerintah, sedangkan pihak yang mengawasi di wilayah intern harus memiliki posisi independen untuk menekan "kultur" negatif yang sebelumnya menunjukkan kurangnya loyalitas dan komitmen dari pemimpin di daerah dan pimpinan lembaga-lembaga. Maka dari alasan itu, seharusnya adanya sinkronisasi antara undang-undangnya dengan tugas dan fungsi pengawas intern tersebut, sehingga kedepannya tidak terjadi kerancuan dan ambiguitas saat melakukan pengawasan intern. ${ }^{49}$

Pada pihak lain, yang menjadi objek pengawasan hukum atau pengawasan yang melanggar norma undang-undang dilakukan oleh badan pengadilan. Pengadilan menguji penormaan kebenaran formilnya dan pengujian perbuatan melawan hukumnya (rechtmatigheid dan onrechtmatigheid). ${ }^{50}$ Selain pengawasan oleh badan peradilan, terdapat pengawasan politik dilakukan oleh Dewan Perwakilan Rakyat yang diperintah oleh konstitusi dan pengawasan yang berada di luar itu dilakukan oleh masyarakat dengan

\footnotetext{
7 Pembangunan, "Warta Pengawasan Kawal Akuntabilitas Dan Pembangunan Mungkinkah APIP Efektif," hlm. 8-9.

48 Maryanto, "Pemberantasan Korupsi Sebagai Upaya Penegakan Hukum," Jurnal Ilmiah CIVIS 2, No. 2 (2012): 1-14, https://doi.org/http://dx.doi.org/10.26877/civis.v2i2/Juli.457, hlm. 6.

49 Tim Badan Pengawas,op.cit.,hlm. 8.

50 Angger Sigit Pramukti dan Meylani Chahyaningsih, Pengawasan Hukum Terhadap Aparatur Negara (Media Pressindo, 2018), https://books.google.co.id/books?id=wyiCDwAAQBAJ\&printsec= frontcover\&hl=id\#v=onepage\&q\&f=false, diakses 27 Maret 2020.
} 
melakukan penilaian atas kebijakan administrasi oleh pemerintah. ${ }^{51}$

Jika melihat modul materi KPK tentang good governance, terdapat dua program untuk membangun kepercayaan publik yaitu: (1) Open Government Partnership merupakan upaya global untuk membuat pemerintah lebih transparan, efektif dan akuntabel dengan lembaga negara yang memberdayakan warga negara dan responsif terhadap aspirasi mereka. Tapi, pekerjaan ini tidak pernah mudah. Dibutuhkan kepemimpinan politik. Dibutuhkan pengetahuan teknis. Dibutuhkan upaya yang berkelanjutan dan investasi. Dibutuhkan kerjasama antara pemerintah dan masyarakat sipil; (2) Open Government Indonesia (OGI). OGI merupakan gerakan yang bertujuan membangun pemerintahan yang lebih terbuka, partisipatif, dan inovatif. Melalui OGI, masyarakat dapat berpartisipasi secara mandiri dalam penyusunan pembuatan kebijakan, sehingga kebijakan yang dilahirkan diharapkan lebih bermanfaat, dinamis, dan mengakar. ${ }^{52}$
Kontrol warga negara terhadap kebijakan atau tindakan pemerintah menghendaki agar pemegang kekuasaan tidak menempatkan rakyat selaku objek pasif, tetapi sebagai subjek aktif. Pemerintah dituntut untuk membicarakan urusan publik bersama rakyat (zegen met burger), bukan memberikan instruksi terhadap rakyat (instrueren tegen burger). Dalam negara hukum demokratis, keterbukaan itu merupakan jaminan (waarborg) yang seharusnya ada, bukan hal yang timbul secara kebetulan (toevaliing)..$^{53}$

Maka dari itu, pengawasan dikatakan bagian terpenting sebagai pengawal dalam setiap pelayanan publik. Pengawasan juga berfungsi untuk meminimalisir atau menghilangkan praktik penyalahgunaan wewenang yang berakibat kerugian negara. Capaian dalam pengawasan ini agar menciptakan kepercayaan di tengah masyarakat. Hal ini karena, sistem organisasi akan mengalami ketimpangan ketika fungsi pengawasan tidak ada atau tidak berjalan sebagaimana mestinya. ${ }^{54}$

51 Ridwan HR, Tiga Dimensi.., op.cit., hlm. 127-128.

52 KPK, Good Governance Dan Pelayanan Publik, Cetakan 1 (Jakarta: Direktorat Pendidikan dan Pelayanan Masyarakat Kediputian Bidang Pencegahan Komisi Pemberantasan Korupsi, 2016), 58, https://aclc. kpk.go.id/wp-content/uploads/2019/07/Modul-good-governance-aclc-kpk.pdf, diakses 5 Mei 2020.

53 Ridwan HR, Tiga Dimensi..., loc.cit.

54 Abdul Haris, "Pengawasan Inspektorat Kabupaten Serdang Bedagai Inspection Function of Inspectorate of Serdang Bedagai Regency Dan Aparat Pengawasan Intern Pemerintah," Jurnal Administrasi Publik Fungsi 6, No. 1 (2016): 75-86, hlm. 82. 


\section{SIMPULAN}

Peran hukum administrasi dalam pengawasan di bidang pelayanan publik telah memberikan kepastian hukum berupa UU No. 30 Tahun 2014, dengan tujuan agar pejabat pemerintah yang berwenang saat mengeluarkan K.TUN palinglama10(sepuluh) hari.Namun, jika keputusan tersebut tidak dikeluarkan, maka dianggap mengabulkan permohonan berupa surat keputusan izin atau dispensasi yang diminta. Apabila keputusan yang sudah dikeluarkan menurut waktu yang telah ditentukan ternyata merugikan, dapat dilakukan permohonan di Pengadilan Tata Usaha Negara terhadap K.TUN tersebut. Kemudian, tindakan malaadiministrasi penyelenggara pelayanan publik dapat dilaporkan kepada Ombudsman. Peran hukum administrasi dalam mengatasi permasalahan KKN di tingkat penyelenggaraan pelayanan publik telah diawasi secara represif yang secara tegas diatur di dalam Pasal 2, 3, 5, dan Pasal 11 UU No. 30 Tahun 2014, serta Pasal 12 UU No. 31 Tahun 1999 yang telah diubah menjadi UU No. 20 Tahun 2001. Sedangkan, pengawasan internal di dalam penyelenggaran pelayanan publik tersebut dilakukan dengan cara preemtif dan preventif. Preemtif adalah pengawasan yang dilakukan oleh atasan dengan pendekatan langsung kepada bawahannya, dan pengawasan preventif yang dilakukan oleh APIP dengan mengantisipasi adanya kerugian keuangan negara atas kebijakan penyelenggara pelayanan publik.
Namun dalam pelaksanaannya, APIP harus diperkuat dari segi fungsi dan kewenangan di dalam UU No. 30 Tahun 2014 tentang Administrasi Pemerintahan melalui legislative review.

\section{DAFTAR PUSTAKA}

Basah, Sjahran. Eksistensi Dan Tolak Ukur Badan Peradilan Administrasi Di Indonesia. Bandung: Alumni, 2014.

BPHN. "Laporan Akhir Tim Kompendium Bidang Hukum Pemerintah Yang Baik," 2007.

Chahyaningsih, Angger Sigit Pramukti dan Meylani. Pengawasan Hukum Terhadap Aparatur Negara. Media Pressindo, 2018.https://books.google. co.id/books?id=wyiCDwAAQBAJ\& printsec $=$ frontcover $\& \mathrm{hl}=\mathrm{id} \# \mathrm{v}=$ onepage $\& \& \mathrm{q}=$ false.

Desiana, Ayu. "Reformasi Birokrasi Pemerintah Daerah Menuju Good Governance." Jurnal Manajemen Dan Pembangunan I, No. 1 (2014): 19-47.

Fadhilah, Nurul Laili. "Urgensitas Ombudsman Dalam Pengawasan Pelayanan Publik." Jurnal Pendidikan Pancasila Dan Kewarganegaraan 28, No. 2 (2015): 130-36.

Fatmawati, Maisaroh, Miftakhul Ulum. "Peranan Pengawasan Fungsional Dalam Sisitem Administrasi Negara 
Kesatuan Repubik Indonesia." Fakultas Ilmu Administrasi. Jakarta, 2019. https://doi.org/.1037//00332909.I26.1.78.

Hafidz, Jawade. "Malfungsi Han Dan Upaya Melakukan Rekonstruksi Sistem Hukum Yang Ada Menuju Hukum Yang Melayani." Jurnal Hukum 28, No. 2 (1970): 841-60. https://doi.org/https://doi.org/ 10.20961/yustisia.v1i2.10644.

Hamidi, Jazim. "Paradigma Baru Pembentukan Dan Analisis Peraturan Daerah (Studi Atas Perda Pelayanan Publik Dan Perda Keterbukaan Informasi Publik)." Jurnal Hukum Ius Quia Iustum 18, No. 3 (2011): 33662. https://doi.org/10.20885/iustum. vol18.iss3.art3.

Harimurti, Irawan. Jaminan Terhadap Pemenuhan Hak Tenaga Kerja Kaitannya Dengan Legalisasi Sistem Pekerja Kontrak Untuk Jangka Waktu Jangka Pendek (Outsourcing) (Analisis Yuridis Terhadap Undang-Undang Nomor 13 Tahun 2003 Tentang Ketenagakerjaan). Surakarta: USM, 2010.

Haris, Abdul. "Pengawasan Inspektorat Kabupaten Serdang Bedagai Inspection Function of Inspectorate of Serdang Bedagai Regency Dan Aparat Pengawasan Intern Pemerintah." Jurnal Administrasi Publik Fungsi 6, No. 1 (2016): 75-86.
Herman, Herman. "Perlindungan Hukum Warga Negara Terhadap Tindakan Pemerintah Dalam Membuat Keputusan Administrasi Negara." Jurnal Komunikasi Hukum (JKH) 1, No. 1 (2015): 44-54. https:// doi.org/10.23887/jkh.v1i1.5012.

HR, Ridwan. "Arti Penting Asas Keterbukaan Dalam Penyelenggaraan Pemerintahan Yang Bebas Dari Korupsi, Kolusi, Dan Nepotisme (KKN)." Jurnal Hukum IUS QUIA IUSTUM 11, No. 27 (16 September 2004): 50-61. https://doi.org/10.20885/ iustum.vol11.iss27.art5.

\section{_. Tiga Dimensi Hukum Adminsitrasi Dan Peradilan Adminstrasi. Yogyakarta: FH UII Press, 2009.}

- Diskresi Dan Tanggung Jawab Pemerintah. Yogyakarta: FH UII Press, 2014.

Indonesia. Undang-Undang Nomor 20 Tahun 2001 tentang Perubahan atas Undang-Undang Nomor 31 Tahun 1999 tentang Pemberantasan Tindak Pidana Korupsi. . Undang-Undang Nomor 37 Tahun 2008 tentang Ombudsman Republik Indonesia. 
- Undang-Undang Nomor 30

Tahun 2014 tentang Administrasi Pemerintahan.

Isnawati. "Perspektif Hukum Dalam Pengawasan Pengelolaan Keuangan Daerah." Jurnal Ilmu Hukum Dan Sosial 29, No. 2 (2013): 95-108.

KPK. Good Governance Dan Pelayanan Publik, Cetakan 1., 58. Jakarta: Direktorat Pendidikan dan Pelayanan Masyarakat Kediputian Bidang Pencegahan Komisi Pemberantasan Korupsi, 2016. https://aclc.kpk.go.id/ wp-content/uploads/2019/07/Modulgood-governance-aclc-kpk.pdf.

Liputan6.com. "Indeks Perilaku Anti Korupsi Indonesia 2019 Meningkat." n.d. https://www.liputan6.com/ bisnis/read/4063890/indeks perilaku-anti-korupsi-indonesia2019-meningkat.

Manan, H. Bagir. Menyongsong Fajar Otonomi Daerah. Yogyakarta: Pusat Studi Hukum Fakultas Hukum Universitas Islam Indonesia, 2001.

Marbun, S.F. Peradilan Administrasi Negara Dan Upaya Administrasi Di Indonesia. Yogyakarta: Liberty Offset, 1997.

. Hukum Adminsitrasi II. Yogyakarta: FH UII Press, 2013.
Asas-Asas Umum Pemerintahan Yang Layak. Pertama. Yogyakarta: FH UII Press, 2014.

- Hukum Adminsitrasi Negara I (Administrative Law I). Yogyakarta: FH UII Press, 2018.

Maryanto, Maryanto. “Pemberantasan Korupsi Sebagai Upaya Penegakan Hukum." Jurnal Ilmiah CIVIS 2, No. 2 (2012): 1-14. https://doi.org/ http://dx.doi.org/10.26877/civis.v2i2/ Juli.457.

Marzuki, Laica. "Pemberlakuan UndangUndang Nomor 30 Tahun 2014 Tentang Administrasi Pemerintahan Dalam Konteks Perkembangan Kompetensi Peradilan Tata Usaha Negara RI." Implementation Science. Vol. 39. Jakarta, 2017. https://doi. org/10.4324/9781315853178.

Muhlizi, Arfan Faiz. "Reformulasi Diskresi Dalam Penataan Hukum Administrasi (Reformulation Of Discretion In The Arrangement Administrative Law)." Jurnal Rechtsvinding 1, No. 1 (2012): 102.

Nodi, Hamzar. “Pertanggungjawaban Pejabat Administrasi Negara Dalam Hal Terjadinya Kerugian Pada Keuangan Negara Dalam Kasus Tindak Pidana Korupsi,"Jurnal Ilmu Hukum Riau 3, No. 1 (2012). 
Pembangunan, Tim Badan Pengawas Keuangan dan. "Warta Pengawasan Kawal Akuntabilitas Dan Pembangunan Mungkinkah APIP Efektif." Warta Pengawasan. Jakarta Timur, 2017.

Puang, Victorianus MH Randa. Hukum Pendirian Usaha Dan Perizinan. Yogyakarta: DEEPUBLISH, 2015.

Resen, Made Gde Subha Karma. "Pengaturan Badan Usaha Miliki Daerah Berdasarkan Bood Governance Dan Good Corporate Governance', Disertasi Kementerian Riset, Teknologi Dan Pendidikan Tinggi Universitas Gadjah Mada Fakultas Hukum." Yogyakarta: Gadjah Mada, 2015.

Soehartono. "Eksistensi Asas-Asas Umum Pemerintahan Yang Baik Sebagai Dasar Pengujian Keabsahan Keputusan Tata Usaha Negara Di Peradilan Tata Usaha Negara." Yustisia Jurnal Hukum 1, No. 2 (2012): 180-93. https://doi.org/10.20961/ yustisia.v1i2.10644.

Statistik, Badan Pusat. "Indeks Perilaku Anti Korupsi 2019.” Jakarta, 2019.

Sudrajat, Tedi. "Perwujudan Good Governance Melalui Format Reformasi." Dinamika Hukum 9, No. 2 (2009): 118-25. https://doi. org/http://dx.doi.org/10.20884/1. jdh.2009.9.2.220.
Taufiqurokhman dan, and Evi Satispi. Perkembangan Manajemen Pelayanan Publik Teori Dan Perkembangan Manajemen Pelayanan Publik. Ed. Pertam. Ciputat, Tanggerang Selatan: UMJ PRESS, 2018.

Yunus, Nur Rohim. "Menciptakan Good and Clean Government." Nur ElIslam 3, No. 1 (2016): 143-75. 
